комендовано осуществлять термообработку с закалкой на аустенит при $1100{ }^{\circ} \mathrm{C}$ в течение 10 минут на толщину образца 1 мм.

Прочностные характеристики по сравнению с исходным состоянием выше, а значения относительного удлинения и сужения сопоставимы с ними. После отжига при $1100{ }^{\circ} \mathrm{C}$ фасетки скола практически исчезают, доля ямочного микрорельефа увеличивается, что свидетельствует о повышении энергоемкости разрушения. Для объяснения явления повышения прочностных свойств при одновременном снижении пластичности нами проведена серия измерений по изучению структуры состаренных материалов методом просвечивающей электронной спектроскопии. Установлено, что упрочнение сплава VDM® Alloy C-4 при длительной выдержке при 550-600 ${ }^{\circ} \mathrm{C}$ связано с выделением фазы $\mathrm{Ni}_{2}(\mathrm{Cr}, \mathrm{Mo})$, упорядоченной по типу $\mathrm{Pt}_{2} \mathrm{Mo}$. Упорядочение приводит к смене механизма деформации от скольжения к двойникованию, которое обычно требует больших напряжений.

С помощью растровой электронной микроскопии (РЭМ) в интервале температур от $500{ }^{\circ} \mathrm{C}$ до $1000{ }^{\circ} \mathrm{C}$ (с максимальным периодом испытаний до 1000 ч и шагом температур $50{ }^{\circ} \mathrm{C}$ ) построена С-образная диаграмма выделения избыточных фаз для сплава VDM® Alloy C-4 различного сортамента. На основании полученных диаграмм оценены минимально допустимые температурновременные условия эксплуатации (например, для сортамента «труба» - свыше 512 ч при температуре $650{ }^{\circ} \mathrm{C}$ и свыше 1000 ч при $600{ }^{\circ} \mathrm{C}$ ), а также рекомендованы скорости охлаждения исследуемого сплава после аустенизации для предотвращения выделения вторых фаз по границам зерен (не менее $4{ }^{\circ} \mathrm{C} /$ мин).

\title{
DEVELOPING WATER-OIL SWELLING THERMOPLASTIC BLEND FOR SEALING SYSTEMS OF WELLS
}

\author{
AkhmedzyanovaD.M. ${ }^{*}$, Galikhanov M.F. \\ Kazan State Technological University, Kazan, Russia \\ *E-mail: damira_2004@mail.ru
}

One of the easiest and most reliable ways to isolate watered flows of oil wells is the use of packers of different designs, among which water swelling or oil swelling ones are considered [1]. Recently, the use of packers capable of swelling in water and in oil spread widely. Such packers are used if the borehole fluid type is unknown.

Materials for the production of swellable packers are generallyelastomeric compositions. However, the complexity of the production process of elastomeric compositions and articles based on them, large power consumption, complexity, wastes formed result in a high cost of the finished products. These problems can be avoided 
by using thermoplastic blend consisting of 25-35\%thermoplastic and 65-75\% elastomer being cured in the process of forming a composite and/or products.

The aim of this work was to develop a water-oil thermoplastic blend for sealing systems of wells.

As a result of the work we obtained thermoplastic blends of various compositions, swelling by $90 \%$ in "oil" media andby $80 \%$ in "oil-field water" and "oil-water". In this case the degree of swelling depended on temperature conditions. In particular, as temperature rises up to $80^{\circ} \mathrm{C}$, the swelling in water increases 1.15 times than at room temperature.

The level of strength properties of the developed thermoplastic blend is low but sufficient for the intended application, as during their operation they are not subjected to heavy wear.

At the same time, for sealing the wells the question of regulated swelling time of thermoplastic blend arises. It is often necessary to postpone the start of the process of swelling or to slow down its speed. A method that allows influencing the rate of interaction of polymer materials with liquid media is transforming a polymer into electret state. It is known [2-5] that the electric field of the electret has a significant effect on wetting processes, absorption and diffusion of liquid in relation to the polymeric material. Therefore, the thermoplastic blend was transferred to the electret state by unipolar corona discharge, which slowed down the process of swelling of hydrosorption materials.

During the operationof blend compositions, their electret state relaxes rapidly, thereafter the swelling process occurs at a specified rate. It allows to perform the installation work in installing or replacing the sealing gaskets based on hydro-sorption mixed thermoplastic blend.

1. KazimovSh.P., AbdullayevaE.S., RacabovN.M., OilGazScientificResearchProjectInstitute, 3, 43 (2015).

2. KestelmanV.N., PinchukL.S., GoldadeV.A., Electrets in Engineering: Fundamentals and Applications, KluwerAcad. Publ., 281 (2000).

3. VertjachihI.M., GoldadeV.A., NeverovA.S., PinchukL.S., Vysokomolek. Soed. Ser. B., 24, 683 (1982).

4. PlevachukV.G., VertjachihI.M., GoldadeV.A., PinchukL.S., Vysokomolek. Soed. Ser. A., 37, 1728 (1995).

5. Galihanov M.F., Borisova A.N., Deberdeev R.Ja., Vysokomolek. Soed. Ser. A., 48, 238 (2006). 